\title{
DIAGNOSTIC UTILITY OF LEUKOCYTE PARAMETERS IN THE PATIENTS WITH ACUTE MYOCARDIAL INFARCTION
}

\author{
*D.V. Zhehestovska, M.V. Hrebenyk \\ I. HORBACHEVSKY TERNOPIL NATIONAL MEDICAL UNIVERSITY, TERNOPIL, UKRAINE
}

Background. Inflammation is one of the key players in acute myocardial infarction (AMI). One of the ways to evaluate it indirectly is to analyze leukocyte parameters of complete blood count (CBC), which is a routine and affordable method of diagnosis. Leukocyte counts can provide additional information about the course, as well as a potential prognosis for complications of AMI. We suggest that the dynamic changes of CBC during the treatment of the patients with AMI may be of value to assess the prognosis of the course of the disease, and therefore require further study.

Objective. The aim of the study to evaluate the diagnostic and prognostic potential of leukocyte indexes of $C B C$, in particular the levels of leukocytes, lymphocytes, neutrophils and N/L, WBC/MPV, PLT/L ratios in the patients with AMI at the time of hospitalization and on the $7^{\text {th }}$ day of hospital stay.

Methods. The study involved 204 individuals: 152 patients with AMI (Group 1), 30 patients with stable coronary heart disease (Group 2) and 24 healthy volunteers (Group 3). Hemogram parameters and their ratios, in particular the levels of leukocytes, lymphocytes, neutrophils, ESR, as well as the ratios of N/L and PLT/L were studied.

Results. Levels of leukocytes, neutrophils, lymphocytes, as well as N/L, WBC/MPV, MPV/L ratios were significantly higher in the patients with AMI compared to other groups. The best diagnostic value had such indicators as the total number of leukocytes (sensitivity 71.7\%, specificity 69.7\%, AUC 0.794), the absolute number of granulocytes (sensitivity $81.7 \%$, specificity $77.4 \%$, AUC 0.803), the N/L ratio (sensitivity $75.0 \%$, specificity $71.7 \%$, AUC 0.791) and the WBC/MPV ratio (sensitivity $76.7 \%$, specificity $62.3 \%$, AUC 0.760). The PLT/L ratio calculated on the $7^{\text {th }}$ day of hospital stay correlated with the risk of in-hospital $(r=0.369, p=0.002)$ and 6 - month mortality $(r=0.338$, $p=0.004$ ) according to the GRACE score.

Conclusions. Leukocytes, granulocytes, N/L and WBC/MPV ratios had a fairly high diagnostic value for the patients with AMI. Regarding the prognostic potential assessment, only the PLT/L ratio on the $7^{\text {th }}$ day of hospitalization correlated with the risk of in-hospital and 6-month mortality. This proves the importance of assessing CBC parameters not only at the time of hospitalization, but also in the dynamics of AMI.

KEYWORDS: inflammation; acute myocardial infarction; complete blood count; leukocytes.

\section{Introduction}

Inflammation plays a key role in the pathophysiology of acute myocardial infarction (AMI), both at the time of its development and later on $[1,2]$. Leukocytes are the main contributors in the formation and subsequent destabilization of fibroatheroma. At the same time, they are closely related to activation of platelets increasing their prothrombotic potential $[3,4]$. Different white blood cell (WBC) subtypes play their own role in this process. There are several studies that prove not only the diagnostic but also the prognostic value of assessment of leukocyte indexes and their ratios in management of the patients with AMI

*Corresponding author: Diana Zhehestovska, PhD student, I. Horbachevsky Ternopil National Medical University, Ternopil, 46000, Ukraine. E-mail: zhehestovska_dv@tdmu.edu.ua
[5-7]. However, most of these works are focused on the complete blood count (CBC) parameters only at the time of hospitalization. We suggest that the dynamic changes of CBC during treatment of the patients with AMI may be of value to assess the prognosis of the disease course and therefore require further study.

\section{Methods}

The study involved 152 inpatients with AMI Group 1. Besides, two more study groups were formed: a comparison group, which included patients with stable ischemic heart disease (SIHD) ( $n=30)$ - Group 2, and a control group of healthy volunteers ( $n=28)$ - Group 3 . The study was carried out at Ternopil City Municipal Hospital No. 2 (Ukraine) in October 2018 - June 2019. 
The diagnosis of AMI was verified following the clinical guidelines $[8,9]$. Clinical symptoms of AMI, in particular the duration of angina pectoris and symptom-to-balloon time, the results of biochemical blood tests, angiographic protocols were evaluated. In addition, the risk of complications for acute coronary syndrome was assessed using the GRACE score [10,11].

Blood sampling was performed from the ulnar vein in the first hour and on the $7^{\text {th }}$ day after hospitalization. CBC was performed using an automated hematology analyzer; in addition, a manual count of leukocyte fractions in peripheral blood was performed, as well as the erythrocyte sedimentation rate measurement (ESR).

Statistical data was processed using the application package SPSS v25.0, as well as Microsoft Excel spreadsheets. The data were presented in the format of "mean \pm standard error of the mean". The significance of the differences between the two independent samples in the case of normal data distribution was determined using the Student's t-test; in the case of abnormal data distribution - the non-parametric Mann-Whitney test. To compare three or more independent samples, one-factor analysis of variances was used - the ANOVA (analysis of variance), in the case of abnormal data distribution - the Kruskal-Wallis ranking criterion.
The ROC analysis was used to identify the diagnostic value of individual ZAK indicators. Such parameters as an area under the curve $(A \cup C)$, as well as the sensitivity and specificity of the test, were analyzed.

The Pearson's correlation analysis was used to assess the relationships between the studied indicators with a normal distribution of data, and the Spearman's correlation analysis - in the case of abnormal distribution. The null hypothesis was denied at $p<0.05$. The correlation coefficient was evaluated according to the following criteria: $r<0.3$ - weak relationship; $r=0.30-0.49$ - moderate; $r=0.50-0.69-$ significant; $r=0.70-0.89$ - strong; $r>0.90$ - very strong, close to the functional association.

\section{Results}

A mean age of the patients with AMI was $(62.91 \pm 10.90)$ years old, among them the male predominated $(n=116,76.3 \%)$. More than half of the subjects had concomitant pathology in the form of hypertension $(n=134,88.16 \%)$ and diabetes mellitus ( $n=29,19.08 \%$ ).

Comparing the parameters of the CBC between the three groups (Table 1) it was established that in the group of patients with AMI the level of leukocytes was significantly higher than in the control and comparison groups. There was no significant difference in

Table 1. Comparison of CBC parameters between the patients with AMI, SIHD and healthy volunteers

\begin{tabular}{|l|c|c|c|c|c|}
\hline & $\begin{array}{c}\text { Group 1 } \\
(\mathrm{n}=152)\end{array}$ & $\begin{array}{c}\text { Group 2 } \\
(\mathrm{n}=30)\end{array}$ & $\begin{array}{c}\text { Group 3 } \\
(\mathrm{n}=24)\end{array}$ & $\begin{array}{c}\text { P-value } \\
(\text { ANOVA })\end{array}$ & P value \\
\hline Age, years & $63.11 \pm 0.89$ & $56.13 \pm 1.66$ & $45.75 \pm 3.30$ & $<0.001$ & $0.01^{\mathrm{a}, \mathrm{b}, \mathrm{c}}$ \\
\hline Men, $\mathrm{n}(\%)$ & $116(76.3)$ & $24(77.4)$ & $17(70.8)$ & $\mathrm{NS}$ & $\mathrm{NS}$ \\
\hline WBC, $10^{9} / \mathrm{L}$ & $9.10 \pm 0.24$ & $6.89 \pm 0.26$ & $6.45 \pm 0.35$ & $<0.001$ & $<0.001^{\mathrm{a}, \mathrm{b}}$ \\
\hline Lymphocytes, $10^{9} / \mathrm{L}$ & $1.85 \pm 0.13$ & $2.14 \pm 0.12$ & $2.40 \pm 0.18$ & 0.038 & $0.023^{\mathrm{b}}$ \\
\hline Monocytes, $10^{9} / \mathrm{L}$ & $0.51 \pm 0.06$ & $0.64 \pm 0.16$ & $0.78 \pm 0.20$ & $\mathrm{NS}$ & $\mathrm{NS}$ \\
\hline Granulocytes, $10^{9} / \mathrm{L}$ & $7.01 \pm 0.41$ & $5.29 \pm 0.94$ & $3.66 \pm 0.33$ & 0.001 & $<0.001^{\mathrm{b}}$ \\
\hline N/L ratio & $5.54 \pm 0.64$ & $2.53 \pm 0.31$ & $1.64 \pm 0.17$ & $<0.001$ & $<0.001^{\mathrm{a}, \mathrm{b}}$ \\
& & & & & $0.015^{\mathrm{c}}$ \\
\hline WBC/MPV ratio & $1.03 \pm 0.05$ & $0.76 \pm 0.03$ & $0.78 \pm 0.04$ & $<0.001$ & $<0.001^{\mathrm{a}}$ \\
& & & & $0.002^{\mathrm{b}}$ \\
\hline MPV/L ratio & $7.00 \pm 0.66$ & $4.63 \pm 0.36$ & $5.13 \pm 0.31$ & 0.001 & $0.002^{\mathrm{a}}$ \\
& & & & & $<0.001^{\mathrm{b}}$ \\
\hline PLT/L ratio & $161.59 \pm 11.86$ & $113.99 \pm 9.07$ & $114.36 \pm 7.83$ & 0.004 & $0.02^{\mathrm{a}}$ \\
& & & & & $0.001^{\mathrm{b}}$ \\
\hline ESR, mm/hour & $11.20 \pm 0.75$ & $8.26 \pm 0.81$ & $7.71 \pm 0.92$ & 0.048 & $<0.05^{\mathrm{a}, \mathrm{b}}$ \\
\hline
\end{tabular}

Notes:

a-comparing groups 1 and 2, b-comparing groups 1 and 3, c-comparing groups 2 and 3.

NS - not significant

WBC - white blood cells, N/L ratio - neutrophils to lymphocytes ratio, WBC/MPV ratio - white blood cells to mean platelet volume ratio, MPV/L ratio - mean platelet volume to lymphocyte ratio, PLT/L ratio - platelet count to lymphocytes ratio, ESR - erythrocyte sedimentation rate. 
the absolute number of lymphocytes and granulocytes between the AMI and comparison groups, but such differences were found when comparing the AMI patients and healthy volunteers: in the AMI group, there was a significantly lower lymphocyte count and higher granulocytes. The N/L ratio differed between the three groups and was the highest in the patients with AMI $(p<0.001)$.

The ratios that simultaneously reflected two links in the pathogenesis of coronary heart disease: inflammation and platelet activation, such as PLT/L, WBC/MPV and MPV/L, were of particular interest. All of them were significantly higher in the patients with AMI, compared with the control and comparison groups.

Taking into account the obtained results of average values comparison, the diagnostic value was determined, as well as the sensitivity and specificity of certain parameters of the CBC in the patients with AMI (Fig. 1).

As seen in Table 2, the indicators such as total leukocyte count, absolute granulocyte count, N/L ratio, and WBC/MPV ratio were of the best diagnostic value.

A negative correlation was found between symptom-to-balloon time and the absolute level of lymphocytes $(r=-0.38 ; p=0.008)$, while the positive correlation was determined with the following indicators: the N/L $(r=0.370$; $p=0.07), P L T / L(r=0.380 ; p=0.06)$ and MPV/L $(r=0.351 ; p=0.011)$ ratios. Also relationships were found between the duration of angina, i.e. the duration of ischemia and the number of granulocytes $(r=0.366 ; p=0.004)$, the $N / L$ $(r=0.370 ; p=0.004)$ and PLT/L $(r=0.260 ; p=0.045)$ ratios and the number of lymphocytes ( $r=-$ $0.268 ; p=0.038$ ).

The relationship between the level of CPK $\mathrm{MB}$ and the $\mathrm{N} / \mathrm{L}$ ratio $(r=0.567 ; p<0.001)$, as well as hematocrit $(r=0.406 ; p=0.004)$ was also established.

Any significant relationships between $C B C$ and prognostic markers of AMI, such as the GRACE score, have not been established at this stage.

The dynamics of general blood test in the patients with AMI were further analyzed (Table 3).

A decrease in the levels of leukocytes and neutrophils was evidenced $(p<0.001$ and $p=0.012)$. Instead, the ESR increased significantly.

\section{Discussion}

High levels of neutrophils in the patients with AMI found in our study are associated with
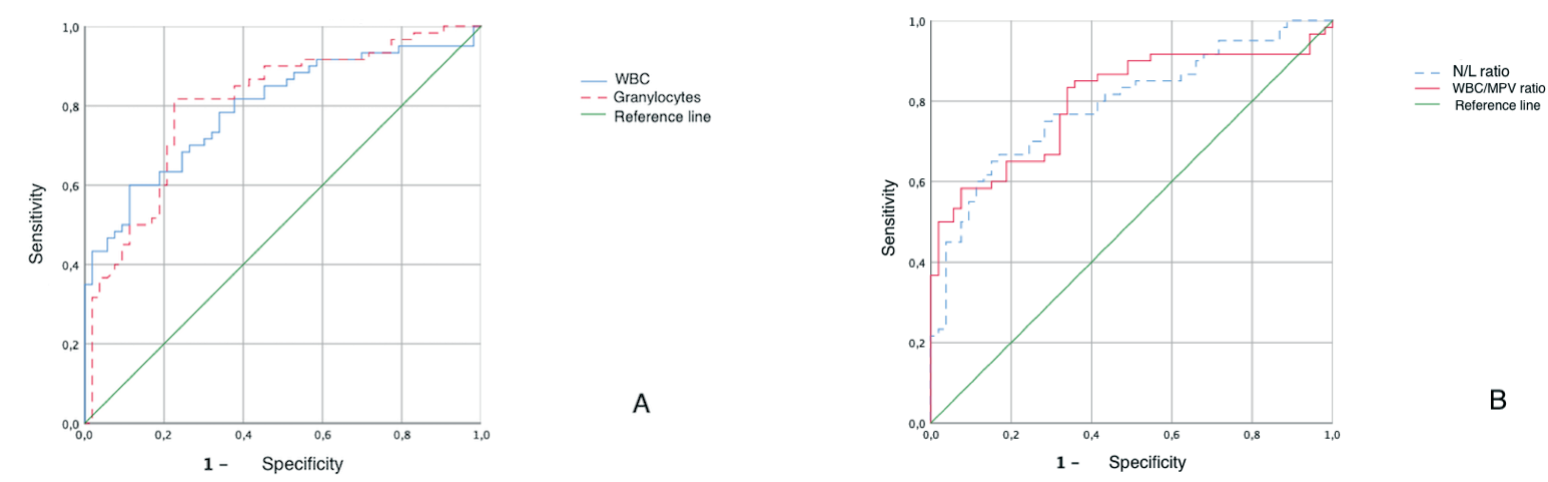

Fig. 1. Receiver operating characteristics analysis of leukocyte parameters in the AMI patients.

Table 2. Diagnostic sensitivity and specificity of the СВC parameters in the AMI patients

\begin{tabular}{|l|c|c|c|c|}
\hline & AUC & Sensitivity, $\%$ & Specificity, \% & Cut-off point \\
\hline WBC, $10^{9} / \mathrm{L}$ & 0.794 & 71.7 & 69.7 & 7.61 \\
\hline Granulocytes, $10^{9} / \mathrm{L}$ & 0.803 & 81.7 & 77.4 & 4.99 \\
\hline N/L ratio & 0.791 & 75.0 & 71.7 & 2.40 \\
\hline PIt/L ratio & 0.654 & 65.0 & 52.8 & 108.49 \\
\hline WBC/MPV ratio & 0.760 & 76.7 & 62.3 & 0.85 \\
\hline MPV/L ratio & 0.051 & 66.7 & 64.2 & 4.44 \\
\hline
\end{tabular}

Notes: AUC - area under the curve. WBC - white blood cells, N/L ratio - neutrophils to lymphocytes ratio, WBC/MPV ratio - white blood cells to mean platelet volume ratio, MPV/L ratio - mean platelet volume to lymphocyte ratio, $P L T / L$ ratio - platelet count to lymphocytes ratio, ESR - erythrocyte sedimentation rate. 
Table 3. Comparison of CBC parameters in the AMI patients at the time of hospitalization and on the $7^{\text {th }}$ day after MI

\begin{tabular}{|l|c|c|c|}
\hline & Day 1 & Day 7 & P value \\
\hline WBC, $10^{9} / \mathrm{L}$ & $9.34 \pm 0.32$ & $8.07 \pm 0.27$ & $<0.001$ \\
\hline Lymphocytes, $10^{9} / \mathrm{L}$ & $2.10 \pm 0.19$ & $2.09 \pm 0.17$ & $\mathrm{NS}$ \\
\hline Monocytes, $10^{9} / \mathrm{L}$ & $0.57 \pm 0.11$ & $0.71 \pm 0.17$ & $\mathrm{NS}$ \\
\hline Granulocytes, $10^{9} / \mathrm{L}$ & $6.74 \pm 0.50$ & $5.30 \pm 0.49$ & $\mathrm{~N}$ \\
\hline N/L ratio & $4.28 \pm 0.63$ & $2.92 \pm 0.29$ & $\mathrm{NS}$ \\
\hline WBC/MPV ratio & $1.06 \pm 0.8$ & $0.88 \pm 0.05$ & 0.015 \\
\hline MPV/L ratio & $7.16 \pm 1.02$ & $4.58 \pm 0.28$ & $\mathrm{NS}$ \\
\hline PIt/L ratio & $141.45 \pm 14.50$ & $145.31 \pm 12.05$ & $<0.001$ \\
\hline ESR, mm/hour & $12.34 \pm 1.21$ & $22.88 \pm 1.45$ & \\
\hline
\end{tabular}

Notes. WBC - white blood cells, N/L ratio - neutrophils to lymphocytes ratio, WBC/MPV ratio - white blood cells to mean platelet volume ratio, MPV/L ratio - mean platelet volume to lymphocyte ratio, PLT/L ratio - platelet count to lymphocytes ratio, ESR - erythrocyte sedimentation rate.

the formation of platelet-leukocyte aggregates in the lumen of the vessel that leads to their increase in the area of myocardial infarction. Also, neutrophils can affect platelet function by direct adhesion or by secretory factors. In contrast, the number of lymphocytes in AMI tends to decrease. We were able to confirm this pattern when comparing patients with AMI and healthy volunteers, at the same time there were no differences in the group of patients with stable coronary heart disease. This can be explained by the fact that the decrease in the number of lymphocytes is associated with physiological stress, which leads to increased cortisol levels and activates the process of apoptosis in the lymphocytes [12]. Thus, in the case of early admission to the hospital, this index may simply not have time to decrease. This is confirmed by the correlation we found, according to which the longer the angina pectoris lasted, the lower the patient's lymphocyte level was.

Given that neutrophils and lymphocytes are the cells with the opposite effect in the context of vascular inflammation, it is important to assess not only their absolute numbers but also the balance between them. One of the potential ways to do this is to evaluate the N/L ratio, which is considered to be an indicator of systemic inflammation [13]. According to our results, it not only significantly differed in the patients from the study and comparison groups, but also proved a significant positive correlation with the marker of myocardial necrosis - CPK MB.

When assessing the hemogram on the $7^{\text {th }}$ day, a significant decrease in the level of leukocytes, due to neutrophils, and an increase in ESR were noted. This phenomenon is also known as the "scissors symptom" or "crossover symptom" and is an evidence of the necroresorptive syndrome, denoted by a systemic inflammatory response to the entry of myocardial breakdown products into the bloodstream. Thus, the number of neutrophils, which is traditionally the highest on the $1^{\text {st }}-3^{\text {rd }}$ day after the development of AMI, dets to norm on the $5^{\text {th }} 7^{\text {th }}$ days due to active phagocytosis of dead neutrophils in the infarct area provided by macrophages [10]. The increase of ESR is caused by the fact that normally the charge of the erythrocyte membrane is negative and this allows them to repel each other. At the same time, pro-inflammatory proteins, in particular fibrinogen and C-reactive protein, have a positive charge and can significantly affect the state of the erythrocyte membrane causing their further aggregation [11].

When assessing the prognostic potential of individual indicators of $\mathrm{CBC}$, we were able to identify it only in relation to the $P L T / L$ ratio on the $7^{\text {th }}$ day of AMI. The fact that the PLT/L ratio correlated with the risk of mortality only in 1 week is most likely explained by the platelet resistance to antiplatelet therapy during the treatment course, as well as to the stimulating effect of inflammation on megakaryocyte proliferation $[14,15]$. The advantage of PLT/L ratio, compared to individual leukocyte and platelet indices, is that it reflects two interdependent processes of inflammation and platelet activation and has already proven to be a good prognostic marker of AMI, in particular regarding the prediction of left ventricular (LV) thrombus, remodeling of LV in the postinfarction period, as well as all-case mortality [14, 16-18]. 


\section{Conclusions}

Levels of leukocytes, granulocytes, lymphocytes, as well as N/L, WBC/MPV ratios, are available and informative markers that provide additional information about the processes of inflammation during the acute phase of myocardial infarction.

We were unable to establish a link between CBC indexes at the time of hospitalization and prognostic factors of AMI. Instead, the parameters that were obtained on the $7^{\text {th }}$ day of treatment, in particular the PLT/L ratio was associated with the risk of in-hospital and 6-month mortality. Thus, we emphasize the importance of assessing the $C B C$ indexes and ratios in the patients with $A M I$ in the dynamics as an inexpensive and informative method for Post-MI risk stratification.

\section{Conflicts of Interest}

Authors declare no conflict of interest.

\section{Author's Contributions}

Diana V. Zhehestovska - investigation, conceptualization, data curation, formal analysis, writing - original draft.

Marian V. Hrebenyk - data curation, writing reviewing and editing.

\title{
ДІАГНОСТИЧНІ МОЖЛИВОСТІ ЛЕЙКОЦИТАРНИХ ПОКАЗНИКІВ СЕРЕД ПАЦІЄНТІВ 3 ГОСТРИМ ІНФАРКТОМ МІОКАРДА
}

\author{
Д.В. Жегестовська, М.В. Гребеник \\ ТЕРНОПІЛЬСЬКИЙ ДЕРЖАВНИЙ МЕДИЧНИЙ УНІВЕРСИТЕТ IMЕНI I. Я. ГОРБАЧЕВСЬКОГО, \\ ТЕРНОПІЛЬ, УКРАЇНА
}

Вступ. Запалення відіграє визначальну роль в процесі розвитку та перебігу гострого інфаркту міокарда (ГІМ). Аналіз лейкоцитарних показників загального аналізу крові (ЗАК) є одним із способів його опосередкованої оцінки, це рутинний і доступний метод діагностики. Ми припускаємо, що динамічні зміни параметрів ЗАК в процесі лікування пацієнтів з ГІМ можуть становити цінність, зокрема і для оцінки прогнозу подальшого перебігу захворювання, а тому потребують подальшого вивчення.

Мета. Оцінити діагностичний та прогностичний потенціал лейкоцитарних індексів ЗАК, зокрема кількісних рівнів лейкоцитів (WBC), лімфоцитів (L), нейтрофілів (N) та співвідношень N/L, WBC/MPV (середнього рівня тпромбоцитів, MPV), PLT/L (співвідношення числа тромбоцитів до кількості лімфоцитів) у пацієнтів з ГІМ на момент госпіталізації та на 7-му добу перебування в стаціонарі.

Матеріали та методи. В дослідженні взяло участь 204 особи (152 пацієнтів з ГІМ (Група 1), 30 пацієнтів з стабільною IXС (Група 2) та 24 здорові добровольці (Група 3)). Досліджували показники гемограми та їх співвідношення, зокрема рівні лейкоцитів, лімфоцитів, нейтрофілів, ШОЕ, а також співвідношень N/L ratio ma PLT/L ratio.

Результати. Рівні лейкоцитів, нейтрофілів, лімфоцитів, а також відношення N/L, WBC/MPV, MPV/L були достовірно вищими серед пацієнтів з ГІМ порівняно із іншими групами. Найкращою діагностичною цінністю володіли такі показники, як загальна кількість лейкоцитів (чутливість 71,7\%, специфічність 69,7\%, AUC 0,794), абсолютна кількість гранулоцитів (чутливість 81,7\%, специфічність 77,4\%, AUC 0,803), відношення N/L (чутливість 75,0\%, специфічність 71,7\%, AUC 0,791) ma WBC/MPV (чутливість 76,7\%, специфічність 62,3\%, AUC 0,760). Співвідношення PLT/L вирахуване на 7-ий день перебування в стаціонарі корелювало з ризиком госпітальної $(r=0,369, p=0,002)$ та 6-ти місячної смертності $(r=0,338 ; p=0,004)$.

Висновки. Показники лейкоцитів, гранулоцитів та співвідношення N/L i WBC/MPV володіли доволі високою діагностичною цінністю серед пацієнтів з ГІМ. Стосовно оцінки прогностичного потенціалу, то лише відношення PLT/L на 7-ий день госпіталізації корелювало з ризиком госпітальної та 6-ти місячної смертності. Це вказує на важливість оцінки ЗАК не лише на момент госпіталізацій, а й в динаміці перебігу ГІМ.

КЛЮЧОВІ СЛОВА: запалення; гострий інфаркт міокарда; загальний аналіз крові; лейкоцити.

Information about the authors

Diana V. Zhehestovska, PhD student, I. Horbachevsky Ternopil National Medical University, Ternopil, Ukraine

ORCID 0000-0001-6305-4143, e-mail: zhehestovska_dv@tdmu.edu.ua

Maryan V. Hrebenyk, Professor, Head of the Department of Therapeutics and Family Medicine, I. Horbachevsky Ternopil National Medical University, Ternopil, Ukraine

ORCID 0000-0002-8118-5742, e-mail: hrebenyk@tdmu.edu.ua 


\section{References}

1. Frangogiannis NG, Smith CW, Entman ML. The inflammatory response in myocardial infarction. Cardiovasc Res. 2002;53:31-47.

2. Ferrari JP, Lueneberg ME, da Silva RL, Fattah T, Gottschall CAM, Moreira DM. Correlation between leukocyte count and infarct size in ST segment elevation myocardial infarction. Arch Med Sci Atheroscler Dis. 2016;1:e44-e48.

3. Italiano JE, Hartwig JH. Chapter 2 - Megakaryocyte Development and Platelet Formation. In: Michelson ADBT-P (Third E (ed). Academic Press; 2013. p. 27-49.

4. Korniluk A, Koper-Lenkiewicz OM, Kamińska J, Kemona H, Dymicka-Piekarska V. Mean platelet volume (MPV): new perspectives for an old marker in the course and prognosis of inflammatory conditions. Mediators of inflammation. 2019 Oct;2019.

DOI: https://doi.org/10.1155/2019/9213074

5. Lassale C, Curtis A, Abete I, van der Schouw YT, Verschuren WMM, Lu Y, Bueno-de-Mesquita HB. Elements of the complete blood count associated with cardiovascular disease incidence: Findings from the EPIC-NL cohort study. Sci Rep. 2018;8:3290.

6. Li J, Wu J, Zhang M, Zheng Y. Dynamic changes of innate lymphoid cells in acute ST-segment elevation myocardial infarction and its association with clinical outcomes. Sci Rep. 2020;10:5099.

7. Khode V, Sindhur J, Kanbur D, Ruikar K Nallulwar S. Mean platelet volume and other platelet volume indices in patients with stable coronary artery disease and acute myocardial infarction: A case control study. J Cardiovasc Dis Res. 2012;3:272-75.

8. Collet J-P, Thiele H, Barbato E, et al. 2020 ESC Guidelines for the management of acute coronary syndromes in patients presenting without persistent ST-segment elevation: The Task Force for the management of acute coronary syndromes in patients presenting without persistent ST-segment elevation of the European Society of Cardiology (ESC). Eur Heart J. 2020.

DOI: https://doi.org/10.1093/eurheartj/ehaa575

9. Ibanez B, James S, Agewall S, et al. 2017 ESC Guidelines for the management of acute myocardial infarction in patients presenting with ST-segment elevation: The Task Force for the management of acute myocardial infarction in patients presenting with ST-segment elevation of the European Society of Cardiology (ESC). Eur Heart J. 2018;39:119-77.

10. Granger CB, Goldberg RJ, Dabbous O, et al. Predictors of Hospital Mortality in the Global Registry of Acute Coronary Events. Arch Intern Med. 2003;163:2345-53.

11. Eagle KA, Lim MJ, Dabbous $\mathrm{OH}$, et al. A Validated Prediction Model for All Forms of Acute Coronary SyndromeEstimating the Risk of 6-Month Postdischarge Death in an International Registry. JAMA. 2004;291:2727-33.

12. Hofmann U, Frantz S. Role of lymphocytes in myocardial injury, healing, and remodeling after myocardial infarction. Circ Res. 2015;116:354-67.

13. Kalay N, Dogdu O, Koc F, Yarlioglues M, Ardic I, Akpek M, Cicek D, Oguzhan A, Ergin A, Kaya MG. Hematologic parameters and angiographic progression of coronary atherosclerosis. Angiology. 2012;63:213-17.

14. Azab B, Shah N, Akerman M, McGinn JT. Value of platelet/lymphocyte ratio as a predictor of allcause mortality after non-ST-elevation myocardial infarction. J Thromb Thrombolysis. 2012;34:326-34.

15. Alexandrakis MG, Passam FH, Moschandrea IA, Christophoridou A V, Pappa CA, Coulocheri SA, Kyriakou DS. Levels of serum cytokines and acute phase proteins in patients with essential and cancer-related thrombocytosis. Am J Clin Oncol. 2003;26:135-40.

16. Zhang Q, Si D, Zhang Z, Wang C, Zheng H, Li S, Huang S, Zhang W. Value of the platelet-tolymphocyte ratio in the prediction of left ventricular thrombus in anterior ST-elevation myocardial infarction with left ventricular dysfunction. BMC Cardiovasc Disord. 2020;20:1-8

17. Bekler A, Gazi E, Yılmaz M, Temiz A, Altun B, Barutçu A, Peker T. Could elevated platelet-lymphocyte ratio predict left ventricular systolic dysfunction in patients with non-ST elevated acute coronary syndrome? Anatol J Cardiol. 2015;15:385-90.

18. Akdag S, Akyol A, Asker M, Ozturk F, Gumrukcuoglu $\mathrm{HA}$. The relation of platelet-lymphocyte ratio and coronary collateral circulation in patients with non-ST segment elevation myocardial infarction. Postep w Kardiol Interwencyjnej. 2016;12:224-30.

Received 28 Oct 2020; revised 9 Dec 2020; accepted 14 Dec 2020.

This is open access article distributed under the Creative Commons Attribution License, which permits unrestricted use, distribution, and reproduction in any medium, provided the original work is properly cited. 